\title{
Characterization of Cell-Death-Inducing Members of the Pectate Lyase Gene Family in Phytophthora capsici and Their Contributions to Infection of Pepper
}

\author{
Li Fu, ${ }^{1}$ Chunyuan Zhu, ${ }^{1}$ Xiaomeng Ding, ${ }^{1}$ Xiaoyan Yang, ${ }^{1}$ Paul F. Morris, ${ }^{2}$ Brett M. Tyler, ${ }^{3}$ \\ and Xiuguo Zhang ${ }^{1}$
}

1Department of Plant Pathology, Shandong Agricultural University, No. 61, Daizong Street, Taian, Shandong, 271018, China;
2Department of Biological Sciences, Bowling Green State University, Bowling Green, OH 43403 U.S.A.; ${ }^{3}$ Center for Genome
Research and Biocomputing, and Department of Botany and Plant Pathology, Oregon State University, Corvallis, 97331, U.S.A.

Submitted 4 March 2015. Accepted 7 March 2015.

Pectate lyases (PL) play a critical role in pectin degradation. PL have been extensively studied in major bacterial and fungal pathogens of a wide range of plant species. However, the contribution of PL to infection by oomycete pathogens remains largely unknown. Here, we cloned 22 full-length pectate lyase (PcPL) genes from a highly aggressive strain of Phytophthora capsici SD33. Of these, PVX agroinfiltration revealed that 12 PcPL genes were found to be highly induced during infection of pepper by SD33 but the induction level was twofold less in a mildly aggressive strain, YN07. The four genes with the highest transcript levels as measured by by quantitative reverse-transcription polymerase chain reaction (PcPL1, PcPL15, PcPL16, and PcPL20) also produced a severe cell death response following transient expression in pepper leaves but the other eight PcPL genes did not. Overexpression of these four genes increased the virulence of SD33 on pepper slightly, and increased it more substantially during infection of tobacco. Overexpression of the genes in YN07 restored its aggressiveness to near that of SD33. Gene silencing experiments with the $12 P c P L$ genes produced diverse patterns of silencing of $P c P L$ genes, from which it could be inferred from regression analysis that PcPL1, PcPL16, and PcPL20 could account for nearly all of the contributions of the PcPL genes to virulence.

The cell wall is a physical barrier that restricts the ingress of phytopathogenic microorganisms and is a target for cell-walldegrading enzymes (CWDEs) secreted by plant pathogens (Cantu et al. 2008). Production of CWDEs is a strategy used by bacteria, nematodes, and fungi to enable invasion (Cantu et al. 2008). The CWDEs not only digest plant cell wall components for nutritional purposes but also physically disrupt the cell wall to aid plant pathogens to penetrate of host cells and spread throughout plant tissues. One important group of CWDEs is the pectin-degrading enzymes, including polygalacturonase (PG), pectate lyases (PL), and pectin methylesterase (PME).

Pectins contribute to both the mechanical strength and the intercellular adhesion of plant cells. Not surprisingly, biotrophic,

L. Fu, C. Zhu, and X. Ding contributed equally to the research.

Corresponding author: X. Zhang; Telephone: +86-538-8249095; Fax: +86-538-8249095; E-mail: zhxg@sdau.edu.cn

*The $\boldsymbol{e}$-Xtra logo stands for "electronic extra" and indicates that nine supplementary figures and six supplementary tables are published online.

(c) 2015 The American Phytopathological Society hemibiotrophic, and necrotrophic plant pathogens employ pectinases, PG (EC 3.2.1.15), PME (EC 3.1.1.11), pectin lyases, and PL (EC 4.2.2.2). To degrade pectins, PL are widely distributed in diverse families of microorganisms and plants. PL cleave the $\alpha-1,4$ glycosidic bonds of polygalacturonic acid (PGA) via a $\beta$-elimination reaction, and play a critical role in pectin degradation (Barras et al. 1994). The resulting oligogalacturonates can act as defense elicitors (De Lorenzo et al. 1991) to activate signaling pathways, resulting in plant resistance (Collmer and Keen 1986; Yoder et al. 1993). PL have been most extensively studied in the bacterium Dickeya dadantii (Erwinia chrysanthemi) and the fungal pathogens Colletotrichum gloeosporioides and C. magna, all of which are major causal agents of diseases in a wide range of plant species (Barras et al. 1994; Collmer and Keen 1986; Kotoujansky 1987). Their action not only results in maceration of plant tissues but also can activate plant defense systems (De Lorenzo et al. 1991; Fagard et al. 2007; Norman-Setterblad et al. 2000; Wattad et al. 1997).

Phytophthora capsici is an oomycete pathogen with significant genetic diversity and is a destructive pathogen of many plant species (Lamour et al. 2012b). As in other Phytophthora spp., the $P$. capsici genome encodes large numbers of potential virulence genes, including CWDEs such as PL. In a previous study, one highly aggressive isolate (SD33) was found to secrete PL earlier than less aggressive isolates (Fu et al. 2013; Jia et al. 2009; Wang et al. 2011a). In this study, 12 PcPL genes were selected for detailed functional analysis during host infection by $P$. capsici. We show that a small number of PcPL proteins that strongly trigger cell death in pepper tissue are primarily responsible for the contributions of these enzymes to virulence.

\section{RESULTS}

Isolation of $P c P L$ genes and sequence analysis.

Forty $P c P L$ coding genes were identified in the available $P$. capsici genome (from strain LT1534) through bioinformatics analyses. We subsequently cloned and verified $22 P c P L$ genes (PcPL1 to $P c P L 22$ ) from the highly virulent $P$. capsici $(P c)$ strain SD33 for further analyses (Supplementary Table S1). The elicitin gene $P \operatorname{cinf} 1$ was also cloned from SD33. Using a consistent bioinformatic strategy, 16 PsPL, 8 PiPL, 17 PpPL, and 10 PrPL gene sequences were identified in the genomes of $P$. sojae, $P$. infestans, $P$. parasitica, and $P$. ramorum, respectively. All 73 encoded PL proteins were predicted to contain signal peptides using SignalPv4.0, except for PcPL3 and PcPL5 (Supplementary Fig. S1). The overall collection of PL sequences was highly diverse, with 
the most divergent members sharing only $21 \%$ amino acid identity. Phylogenetic analysis indicated that the 73 PL sequences could be grouped into two clusters. Cluster I contained $24 \mathrm{PL}$ sequences (6 PcPL, 5 PiPL, 5 PpPL, 4 PsPL, and 4 PrPL). These 24 PL sequences shared a minimum of $42 \%$ amino acid identity. Cluster II contained $49 \mathrm{PL}$ sequences which shared at least $34 \%$ amino acid identity. Individual $P c P L$ genes grouped with $P L$ gene models from other genomes.

All 73 PL sequences possess the three conserved domains (AxDIKGxxxxVTxS, VxRxPxxRxxxxHxxxN, and vWiDH) that are used to characterize a peptide sequence as a PL. In all, 24 PL sequences in cluster I matched the "Pectate_lyase" domain (Charkowski et al. 1998) (CDD: 251801; pfam03211; CAZY family PL3), and 49 PL sequences in cluster II matched the "Pec_lyase_C" domain (Yoder et al. 1993) (CDD: 214765; pfam00544; CAZY family PL1). All of these PL sequences possess the common conserved domain "WxDx" (Supplementary Figs. S2 and $\mathrm{S} 3$, red circle block). In addition to the WxDx domain, several other conserved domains were present in cluster I (Supplementary Fig. S2, blue circle block) and cluster II (Supplementary Fig. S3, blue circle block).

\section{Expression patterns of $P c P L$ genes during $P$. capsici infection.}

When pepper leaves of the susceptible line 06221 were inoculated with zoospores of $P$. capsici SD33, water-soaked lesions were first evident from 1 to 2 days postinoculation (dpi). The lesions then started to exhibit cell death, which gradually became more extensive from 3 to $7 \mathrm{dpi}$ (data not shown). At $7 \mathrm{dpi}$, RNA of the pathogen could still be extracted from the lesions. Of the 22 predicted PcPL genes, 5 (PcPL3, PcPL5, $P c P L 6, P C P L 7$, and $P C P L 8)$ produced no detectable mRNA transcripts at any stage of infection, and 5 others ( $P c P L 10$, PcPL12, PcPL13, PcPL21, and PcPL22) produced only faintly

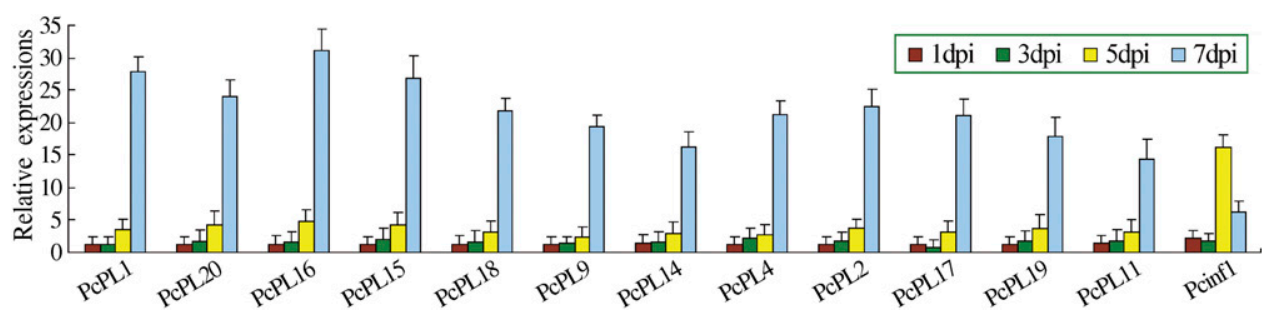

Fig. 1. Transcription pattern of 12 most highly expressed $P c P L$ genes. Quantitative reverse-transcription polymerase chain reaction analysis of expression patterns of 12 PcPL genes and Pcinf1 in Phytophthora capsici isolate SD33 inoculated onto pepper leaves. Data represent the average of three independent experiments with standard errors; dpi $=$ days postinoculation.

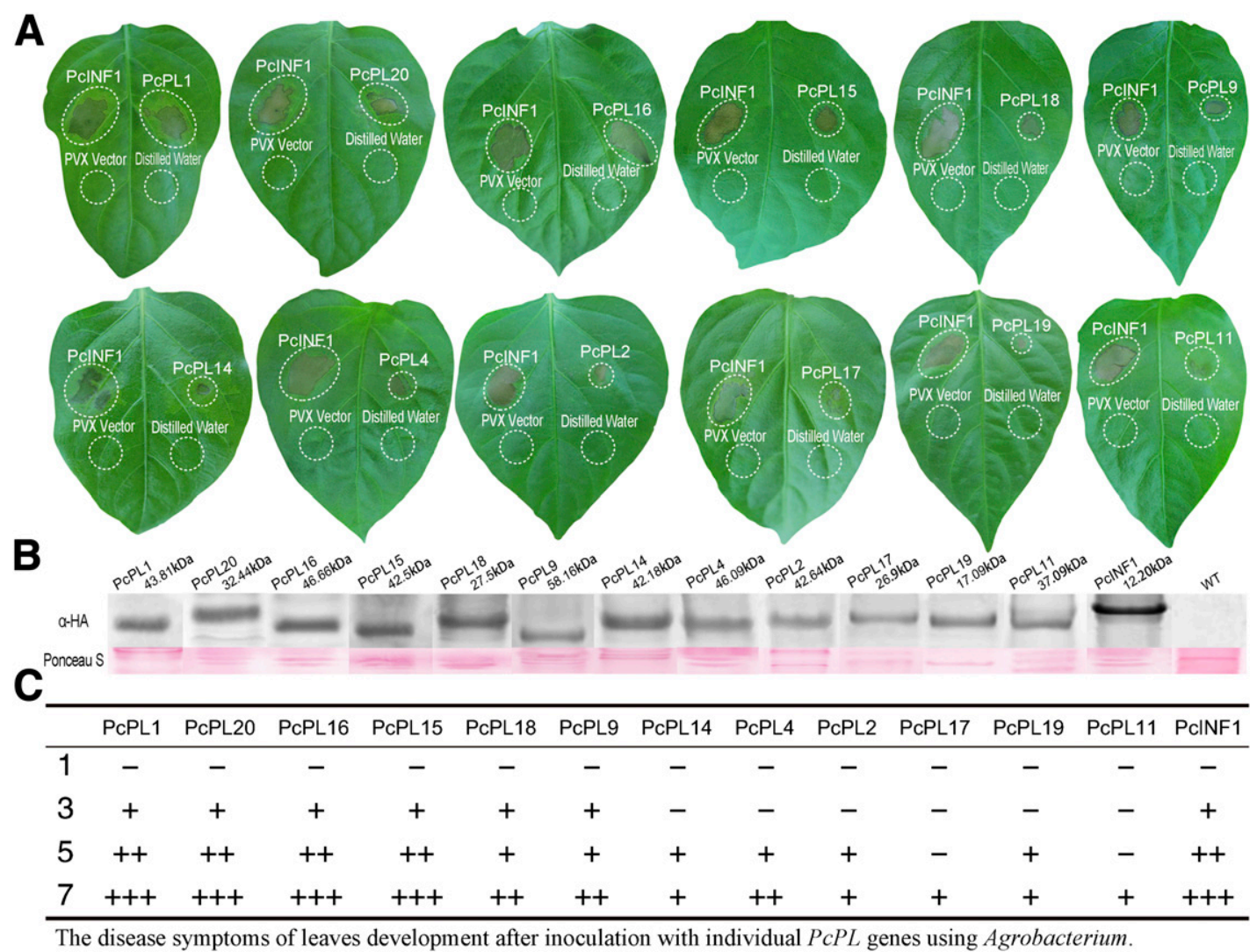

Fig. 2. Comparative analysis of cell death induced by each $P c P L$ gene. A, Cell death caused by inoculation with Agrobacterium tumefaciens cells carrying PVX pGR106 containing individual PcPL genes or the positive control gene Pcinf1. B, Western blot of the PCPL or PcINF1 proteins secreted following agroinfection. WT $=$ proteins extracted from pepper leaves. $\mathbf{C}$, Degree of cell death induced by each $P c P L$ gene at different times postinoculation; $-=$ no cell death, $+=$ weak cell death,$++=$ moderate cell death, and $+++=$ strong cell death. 
detectable transcripts (data not shown). The expression of the remaining $12 P c P L$ genes gradually increased from 1 to $7 \mathrm{dpi}$, reaching the highest levels at $7 \mathrm{dpi}$ (Fig. 1). In comparison, Pcinf 1 showed maximum expression levels at $5 \mathrm{dpi}$. At $7 \mathrm{dpi}$, four genes

A
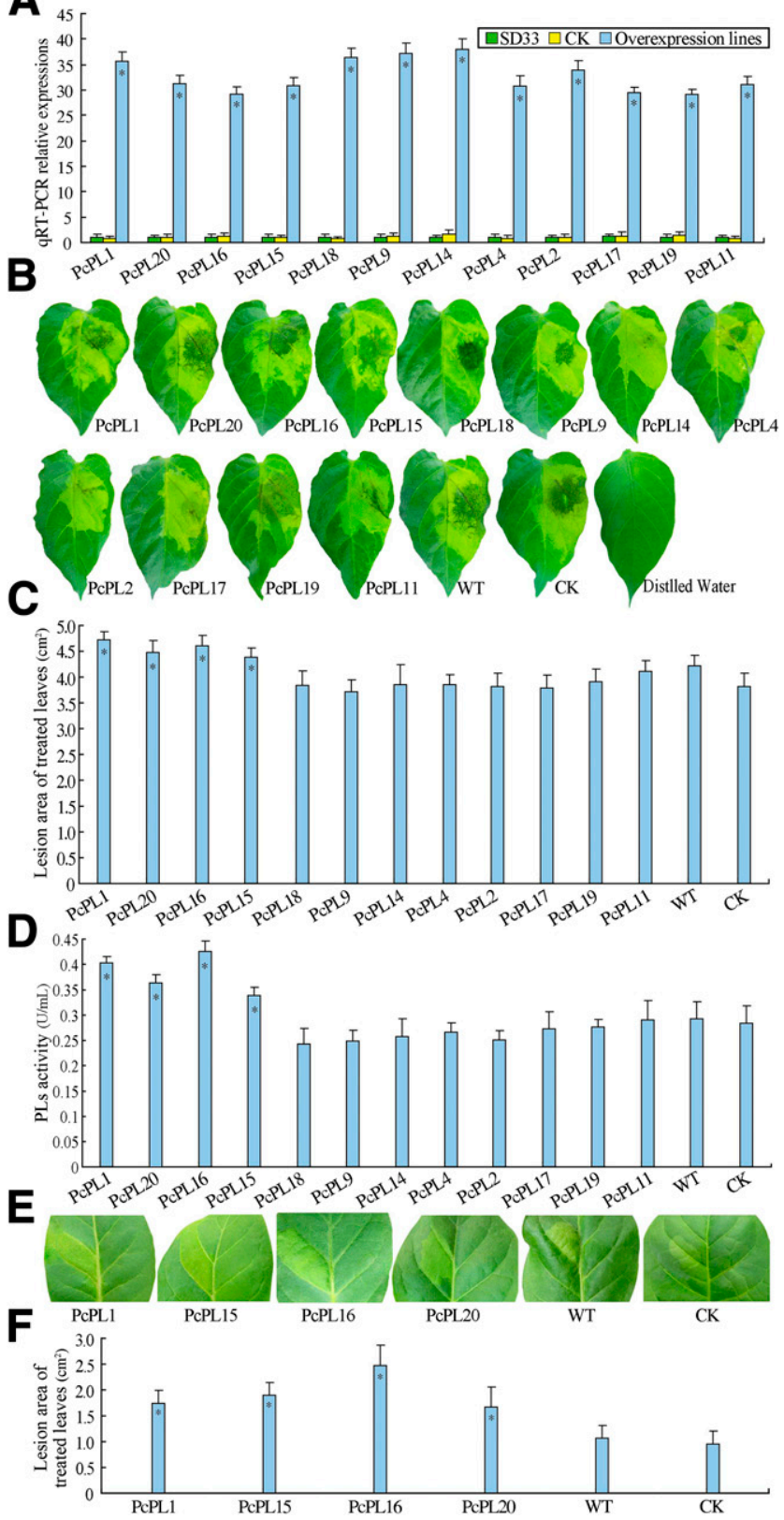

Fig. 3. Functional analyses of 12 Phytophthora capsici lines overexpressing individual $P C P L$ genes. Lines overexpressed the following genes: PCPL1 (1O31), PcPL2 (2-O4), PcPL4 (4-O3), PcPL9 (9-O7), PcPL11 (1-O3), PcPL14 (14-O1), PcPL15 (15-O4), PcPL16 (16-O12), PcPL17 (17-O14), PcPL18 (18O4), PcPL19 (19-O5), or PcPL20 (20-O6). A, Quantitative reverse-transcription polymerase chain reaction (qRT-PCR) analysis of mRNA expression levels of each targeted $P C P L$ gene in individual overexpressed line, relative to the constitutive control genes. Error bars represent confidence intervals calculated using three replicates. B, Symptoms on pepper leaves after inoculation with individual overexpression lines and wild-type (WT) and check (CK) controls. Distilled water was used as a negative control. $\mathbf{C}$, Areas of lesions on pepper evaluated at 5 days postinoculation (dpi). Bars represent the mean \pm standard error of 14 pepper leaves. D, Activity of pectate lyase (PL). E, Symptoms on tobacco leaves after inoculation with four targeted overexpressed lines or with $P$. capsici WT and CK controls. F, Areas of lesions on tobacco were evaluated at $5 \mathrm{dpi}$. Bars represent the mean \pm standard error of 14 tobacco leaves. In A, C, D, and F, an asterisk $\left(^{*}\right)$ indicates that the mean of overexpression transformant is significantly different from WT and CK in a paired $t$ test $(P<0.05)$.
(PCPL1, PcPL15, PcPL16, and PCPL20) showed the strongest expression levels while three others (PCPL11, PcPL14, and $P C P L 19)$ showed the lowest expression (approximately twofold lower). The five others (PcPL2, PcPL4, PcPL17, PcPL18, and $P c P L 9)$ showed intermediate expression levels. The 12 wellexpressed genes were subjected to further functional analysis.

\section{Cell death induced by expression of $P c P L$ genes in pepper by agroinfiltration.}

To determine whether individual PcPL proteins were capable of inducing cell death in pepper, we agroinfiltrated leaves of the inbred line 06221 using the PVX vector pGR106 carrying each of the PcPL genes, and assessed the extent of cell death by the area of tissue collapse (Fig. 2A). Western blot analysis was used to confirm the expression of PcINF1 and PcPL proteins in the pepper tissue (Fig. 2B). Distilled water and Agrobacterium cells with the empty vector pGR106 did not cause any chlorosis or cell death. Pcinf 1 expression caused more extensive leaf cell death than any of the $P c P L$ genes. Expression of each of the $P C P L$ genes produced a certain degree of cell death (Fig. 2A and C). Four PcPL genes (PCPL1, PcPL15, PcPL16, and $P c P L 20)$ caused a strong cell death phenotype, with the largest dead areas at $7 \mathrm{dpi}$. Eight others induced various lower levels of cell death at $7 \mathrm{dpi}$. Of the genes triggering a strong cell death response, $P c P L 1, P c P L 15$, and $P c P L 16$ belong to cluster II, annotated as Pec_lyase_C, while PcPL20 belongs to cluster I, annotated as Pectate_lyase.

\section{Overexpression of some $P c P L$ genes \\ in $P$. capsici transformants increases virulence.}

To obtain additional information regarding the potential functions of the 12 targeted $P c P L$ genes during $P$. capsici infection, we generated $P$. capsici overexpression lines by protoplast transformation. In total, 60 to 80 putative overexpression transformants were obtained exhibiting elevated transcript levels of the targeted genes. Because the growth and morphological phenotypes of all lines were no different than SD33 and a check (CK), we evaluated in detail a single overexpressed line for each targeted gene (Fig. 3, legend). Relative to the transcript levels in SD33 and CK, all overexpression lines had highly increased transcript levels (30- to 40-fold) of each targeted gene (Fig. 3A). The virulence of each overexpression line was evaluated in both pepper (line 06221) and tobacco (Nicotiana tabacum L., NC89). In each case, leaves of the plants were inoculated with a suspension of zoospores.

In the case of pepper, four overexpression lines-1-O31 (PcPL1), 15-O4 (PcPL15), 16-O12 (PcPL16), and 20-O6 $(P c P L 20)$ - exhibited a significantly $(P<0.01)$ larger lesion sizes (Fig. 3B, C) or increased PL levels (Fig. 3D); however, the increases were very modest (3 to $10 \%$ in lesion size and 20 to $50 \%$ in PL levels) compared with the two controls (SD33 and $\mathrm{CK}$ ). The eight other overexpression lines showed no significant increases over the two controls (Fig. 3B, C, and D). In each case, the presence of tissue cell death in the lesions was confirmed by trypan blue staining (Supplementary Fig. S4 A and B). Tobacco is a poor host for P. capsici and, as shown in Figure $3 \mathrm{E}$ and $\mathrm{F}$, inoculation of the leaves with a zoospore suspension from the two controls only produced chlorosis that was restricted to the site of inoculation. In contrast, however, the four overexpression lines 1-O31 (PcPL1), 15-O4 (PcPL15), 16-O12 (PcPL16), and 20-O6 (PcPL20) produced spreading chlorotic lesions that were 2.0- to 2.5-fold larger than the two controls (Fig. 3E and F). Overexpression of the eight other targeted genes did not induce spreading chlorotic symptoms around the inoculation sites (not shown). The increased aggressiveness of SD33 transformants overexpressing $P c P L 1, P c P L 15, P c P L 16$, and $P c P L 20$ suggested that these four genes, which also triggered strong cell death 
in pepper or tobacco leaves, could be important virulence factors in P. capsici.

\section{Cloning of PcPL genes}

from a mildly aggressive $P$. capsici strain.

Because overexpression of PcPL1, PcPL15, PcPL16, and $P c P L 20$ caused only modest increases in the virulence of SD33, which is already a highly aggressive strain, we assessed the contributions of these genes to the virulence of a mildly aggressive $P$. capsici srain, YN07. First, we cloned these four genes and also PcPL4 (which induced mild cell death) from the DNA of YN07, using polymerase chain reaction (PCR) (Supplementary Table S2 for the primers). The genes cloned from YN07 were sequenced (GenBank accession numbers PcPL1: KF133976; PcPL4: KF133977; PcPL15: KF133978; PCPL16: KF133979; and PcPL20: KF133980) and their encoded protein sequences were compared with those cloned from SD33 (Supplementary Figs. S5 to S9). In every case, the protein sequences were nearly identical. PcPL1 (K197E), PcPL4 (A422T), and PcPL16 (R212Q) each showed a single amino acid difference between the two strains, while PcPL15 (R157W, D255N, and R387W) showed three differences. None of the substitutions occurred in conserved sequences known to be important for PL activity.

When pepper leaves are inoculated with zoospores of YN07, water-soaked lesions do not appear until 3 to $5 \mathrm{dpi}$, and only small areas of cell death are apparent by 7 dpi (Fig. $4 \mathrm{~A}$ and $\mathrm{B})$. As in SD33, the expression of the five targeted genes (PcPL1, PcPL15, PcPL16, PcPL20, and PcPL4) in YN07 increased strongly from 3 to 7 dpi (Fig. 4C). However, the level of induction of the genes by 7 dpi was substantially less than in SD33 (8- to 15-fold compared with 25- to 31-fold).

\section{Overexpression of four crucial $P c P L$ genes substantially increases the virulence of the mildly aggressive strain YN07.}

To examine whether the aggressiveness of YN07 could be enhanced by overexpression of the four genes $P c P L 1, P c P L 15$, $P c P L 16$, and PcPL20, 15 stable lines overexpressing these four genes (and PCPL4 for comparison) were obtained. The transformants were screened by the intensity of bands produced by PCR (data not shown) and then validated by the high transcript levels measured by quantitative reverse-transcription (qRT)PCR (Fig. 4D). Wild-type (WT) (YN07) and CK (YN07 transformants containing pHspNpt empty vector DNA) were used as controls. The 15 overexpression lines did not differ from YN07 and CK in growth or morphology (data not shown). Thus, only a single overexpression transformant of each targeted gene was characterized in more detail (Fig. 4, legend). In vitro-grown cultures of these four lines contained increased transcript levels of the overexpressed PCPL genes (26- to 34fold increased), which was much higher than the normal induction level in YN07 (8- to 15-fold at $7 \mathrm{dpi}$ ) and comparable with the induction level in SD33 (25- to 31-fold at $7 \mathrm{dpi}$ ) (Fig. 4D). The lesions obtained with the lines overexpressing $P c P L 1, P c P L 15, P c P L 16$, or PcPL20 were larger than those with YN07 or CK (2.2 to $3.2 \mathrm{~cm}^{2}$ compared with 1.3 to $1.4 \mathrm{~cm}^{2}$ ) (Fig. 4A and B) but were still not as large as produced by aggressive isolate SD33 $\left(4.2 \mathrm{~cm}^{2}\right)$ (Fig. 3B and C). The lesions of the four overexpression lines also exhibited higher PL activities compared with WT and CK (Fig. 4E). In contrast, transformant 4-O4, overexpressing $P c P L 4$, did not produce larger lesions or elevated PL levels. Thus, the aggressiveness of the mildly aggressive isolate (YN07) could be significantly enhanced by overexpressing any of the four cell-death-inducing genes PcPL1, PcPL15, PcPL16, and PcPL20 but not PcPLA.
Silencing of $P c P L$ genes in $P$. capsici transformants identified $P \boldsymbol{P P L}$ genes that contribute to virulence.

To more directly assess the contributions of the $12 P c P L$ genes to virulence, DNA transformation of SD33 protoplasts was used to create stable silenced lines for each of the genes. Thirty-three putative transformants were verified by qRT-PCR compared with SD33 and a CK (SD33 transformed with pHspNpt empty vector DNA). Among these 33 lines, no morphological differences were observed compared with SD33 and CK (data not shown). For further characterization in subsequent experiments, a single line for each targeted gene was selected (Fig. 5A, legend). Overall, the transcript levels of individual targeted genes varied in different silenced lines. In most lines, several genes were simultaneously silenced to various levels, presumably due to sequence similarity among the PcPL paralogs (Supplementary Table S3). Typically, transcripts from the targeted genes were reduced two- to fourfold, whereas the trasncripts from cosilenced genes were reduced less than twofold (Fig. 5D). For example, four PcPL genes (PcPL1, PcPL14, PcPL15, and PcPL16), sharing a sequence similarity of $>50 \%$ were simultaneously silenced to varying extents in the lines 1-S4, 14-S4, 16-S11, and 15-S6.

To test the virulence of the silenced lines, leaves of pepper line 06221 were inoculated with zoospores from each of the silenced lines. The aggressiveness of the transformants was evaluated based on lesion size after 5 days (Fig. 5A and B). SD33 and CK had large ( 3.8 to $4.2 \mathrm{~cm}^{2}$ ) water-soaked lesions by $5 \mathrm{dpi}$. Four lines-1-S4 (PcPL1), 20-S5 (PcPL20), 16-S11 (PcPL16), and 15-S6 (PcPL15) - produced significantly smaller lesions (approximately 0.8 to $1.8 \mathrm{~cm}^{2}$ ) (Fig. 5A to C). Decreases in the levels of PL activity in the infected tissue correlated with decreases in the lesion areas (Fig. 5C), consistent with the level of colonization of the tissue by the pathogen in each case. However, eight other lines did not exhibit reduced virulence or PL activity (Fig. 5A-C). Together, these results indicate that the combined silencing of PcPL1, PcPL15, $P c P L 16$, and PcPL20 severely affects the virulence of $P$. capsici.

The patterns of gene silencing were examined in more detail in the four lines showing the greatest reduction in virulence. In 1-S4 (silenced with $P c P L 1$ ), PcPL1 transcript levels were reduced to $28 \%$ of $\mathrm{WT}$, while $P c P L 15$ and $P c P L 16$ were reduced to 60 and $65 \%$ of WT, respectively (Fig. 5D). In 16-S11 (silenced with $P c P L 16$ ), PcPL16 transcripts were reduced to $30 \%$ of WT, while $P c P L 1, P c P L 14$, and $P c P L 15$ were reduced to 65,68 , and $68 \%$, respectively (Fig. 5D). In 20-S5, silenced with PcPL20, PcPL20 transcripts were reduced to $38 \%$ while $P c P L 18$ transcripts were reduced to $71 \%$ (Fig. 5D). In general, genes from cluster I (e.g., PcPL20) were only silenced when a cluster I gene was used as the trigger, whereas genes from cluster II (e.g., PcPL1) were only silenced when a cluster II gene was used as the trigger. Therefore, from this dichotomy, it could be concluded from the silencing results that some subset of cluster I genes and also some subset of cluster II genes was required for full virulence.

To further dissect the potential roles of the cluster I and II genes to virulence, correlation and regression analyses were performed across all transformants in which cluster I or II genes, respectively, were silenced (Fig. 6). Among the cluster II genes, PcPL1 levels showed a correlation of $r=0.88$ with lesion diameter [LD; calculated as $2 \times \sqrt{ }($ lesion area/ $\pi$ )] (Fig. 6A), while PcPL15 and PcPL16 showed correlations of 0.58 and 0.83 , respectively (Fig. 6B and C). Among the cluster I genes, PcPL20 showed a correlation of 0.99 with LD (Fig. 6D). No other cluster I or cluster II gene transcript levels showed a significant correlation with LD. Among the cluster II genes, a linear model consisting of $0.56 \times P c P L 1+0.44 \times P c P L 16$ provided the best explanation of the variation in the LD ( $r=$ 0.94) (Fig. 6E). Adding PcPL15 to the model did not improve 
the correlation (Fig. 6G), and the best model involving PCPL1 and $P C P L 15(0.88 \times P C P L 1+0.12 \times P c P L 15)$ showed a correlation of 0.89 , barely better than $P c P L 1$ alone (Fig. $6 \mathrm{~F}$ ). Based on this analysis, we infer that PcPL1, PcPL16, and PCPL20 make the most important contributions to virulence. Loss of virulence caused by using any of the other genes for silencing, including $P C P L 15$, could be almost fully explained by cross-silencing of PCPL1, PcPL16, or PCPL20.

\section{DISCUSSION}

The genome sequences of Phytophthora spp., including $P$. sojae, $P$. infestans, $P$. ramorum, and $P$. capsici, have revealed large diverse families of potential virulence genes (Haas et al. 2009; Lamour et al. 2012a; Tyler et al. 2006). These include families of host-cytoplasm-targeted effectors, such as RxLR and CRN effectors (Birch et al. 2008; Dong et al. 2011; Jiang et al. 2008; Morgan and Kamoun 2007; Song et al. 2013; Tyler et al. 2006; Wang et al. 2011b; Win et al. 2007), and apoplasttargeted proteins such as proteinases, protease-inhibitors, celldeath-inducing toxins, lipid transfer proteins, PL, and other carbohydrate-active enzymes. Cytoplasm-targeted effectors, which have been extensively studied, primarily act to suppress plant immunity and cell death during the biotrophic stage of infection (Wang et al. 2011b). Cell death-inducing toxins such as necrosis-inducing proteins (NLP) appear to act at the transition to necrotrophy (Feng et al. 2014). However there has been little study of the roles of carbohydrate-active enzymes or other virulence proteins required during the necrotrophic stage of infection. Here, by using transcriptional profiling, screening of enzyme activities, and gene silencing, we have shown that distinct subsets of PL genes are separately required for the ability of $P$. capsici to produce a necrotic infection of pepper.

Comparison of the 22 PcPL genes identified in the $P$. capsici genome with PL genes predicted from other Phytophthora genomes revealed that the Phytophthora PL superfamily is large and diverse. Two broad clusters and a number of subclusters were evident in the tree but, in many cases, the bootstrap support for the separation of the subclusters was modest (50 to $90 \%$ ), due to the extensive sequence diversity. Although most subclusters within the tree contained representatives from each Phytophthora sp., there was no regular pattern of orthologs, consistent with a rapid rate of gene duplication and deletion. Of the $22 P c P L$ genes identified, only 12 exhibited substantial levels of expression (Fig. 1). All of the subclusters contained at least one member that was well transcribed, suggesting that the subclusters might have distinct functional roles. On the other hand, all 12 genes showed a similar expression profile during infection, being most strongly expressed late in infection (5 to $7 \mathrm{dpi}$ ).

Silencing experiments with each of the 12 strongly expressed $P c P L$ genes revealed that only four of the $P C P L$ genes produced substantial decreases in virulence when used for silencing; namely, PcPL1, PcPL15, PcPL16, and PcPL20 (Fig. 5A and $B)$. The decreases in lesion area correlated with the levels of PL activity in the infected tissue, consistent with levels of colonization of the tissue by the pathogen in each case. In each transformant, more than one $P c P L$ gene was actually partially or fully silenced. In general however, genes from cluster I were only silenced when a cluster I gene was used as the trigger, while genes from cluster II (e.g., PcPL20) were only silenced when a cluster II gene was used as the trigger. From this division, it could be concluded from the silencing results that some subset of cluster I genes and also some subset of cluster II genes were required for full virulence.

When correlation and regression analyses were used to dissect the contributions of the different $P c P L$ genes to virulence, a linear model based on the levels of PcPL1 and PcPL16 transcripts provided the best explanation of the contribution of cluster II enzymes to $P$. capsici virulence, whereas $P c P L 20$ appeared to be solely responsible for the contribution of cluster I
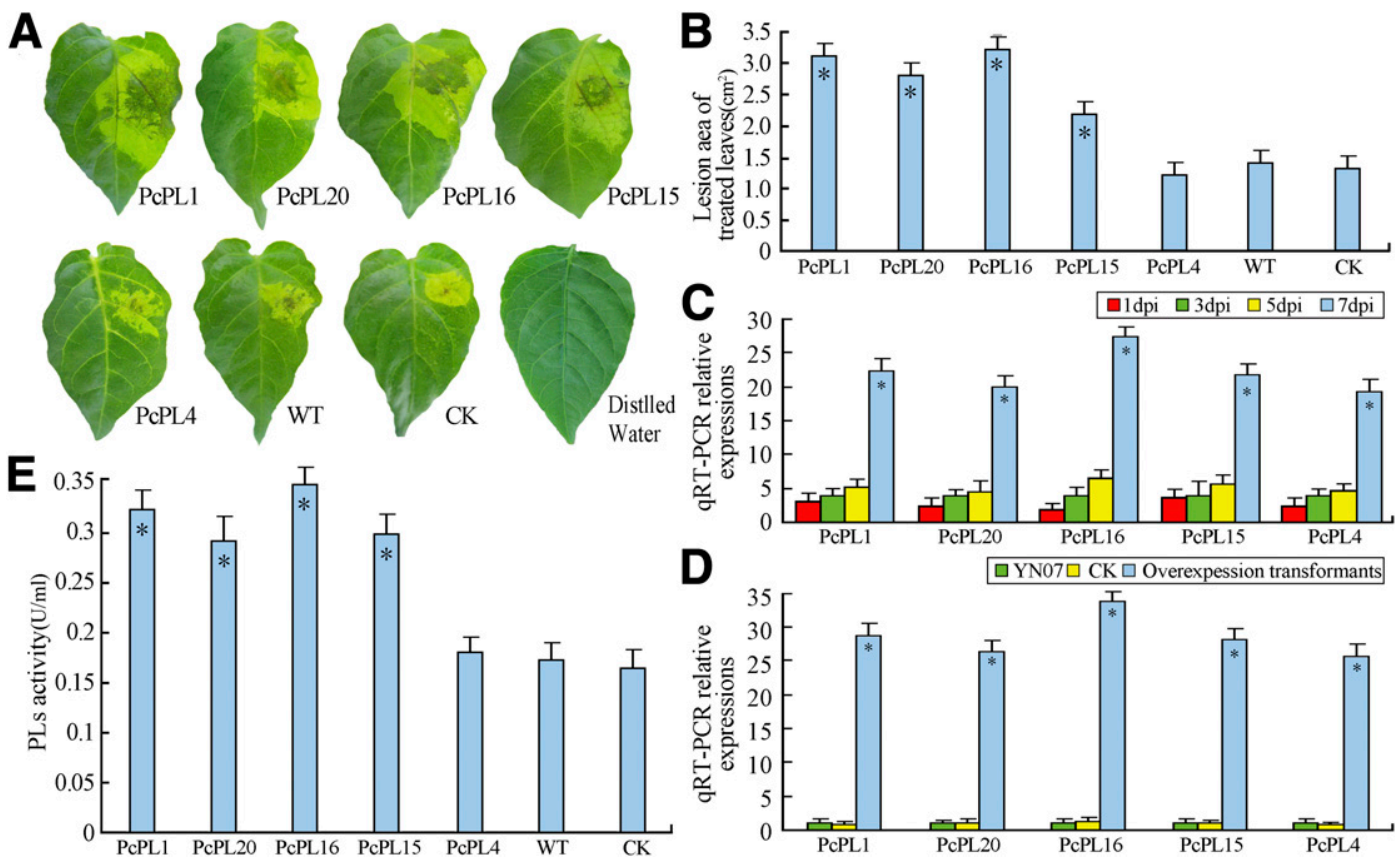

Fig. 4. Impact of $P C P L$ gene overexpression in the mildly aggressive isolate YN07. Lines analyzed were overexpression transformants Y1-O9 (PcPL1), Y15O10 (PcPL15), Y16-O12 (PcPL16), Y20-O4 (PcPL20), Y4-O4 (PcPL4), wild-type strain YN07 (WT), or YN07 transformed with empty vector (CK). A, Symptoms on pepper leaves at 7 days postinoculation (dpi) with individual overexpressed line or controls. B, Areas of lesions evaluated at 7 dpi. Bars represent the mean \pm standard error of 14 leaves. C, Quantitative reverse-transcription polymerase chain reaction (qRT-PCR) analysis of natural transcript levels of $P c P L$ and $P \operatorname{cinf} 1$ genes in WT YN07 at different time points, relative to the constitutive control genes. D, qRT-PCR analysis of transcript levels of each $P c P L$ gene in each overexpressed line and in the controls, relative to the constitutive control genes. E, Activity of pectate lyase (PL) in lesion tissue. In B, C, and E, an asterisk $(*)$ indicates that the mean is significantly different from WT and CK in a paired $t$ test $(P<0.05)$. 
enzymes to virulence. This analysis was conducted using lesion areas and transcript levels measured at 5 dpi in pepper; therefore, we cannot rule out that other $P c P L$ genes make more important contributions at other time points or in other host species.

When the individual $P c P L$ genes were transiently overexpressed in leaves of inbred pepper line 0622, PcPL1, PcPL15, PcPL16, and $P c P L 20$ induced the strongest necrotic responses (Fig. 3B and C), suggesting that their contributions to virulence may be connected to their ability to trigger cell death and tissue collapse in host tissue. This was supported by the observation that only these four genes significantly (albeit slightly: 3 to 10\%) increased the virulence of SD33 when overexpressed in transformants. Similarly, overexpression of these four genes, including $P c P L 15$, in the weakly virulent isolate YN07 could restore its virulence to levels comparable with SD33. The expression levels of the $P C P L$ genes in YN07 generally were approximately half of the level in SD33 (Fig. 4D) but the expression levels in the SD33 and YN07 overexpression transformants were comparable. Thus, the levels in the transformants were slightly higher than the levels in WT SD33 at $7 \mathrm{dpi}$, and approximately twice as high as the levels in WT (YN07) at 7 dpi. Therefore, the virulence of SD33, YN07, and their transformants correlated well with the levels of $P C P L$ gene expression. Although the silencing results suggested that PcPL1, PcPL16, and PcPL20 were together required for full virulence, the overexpression results suggested that overexpression of

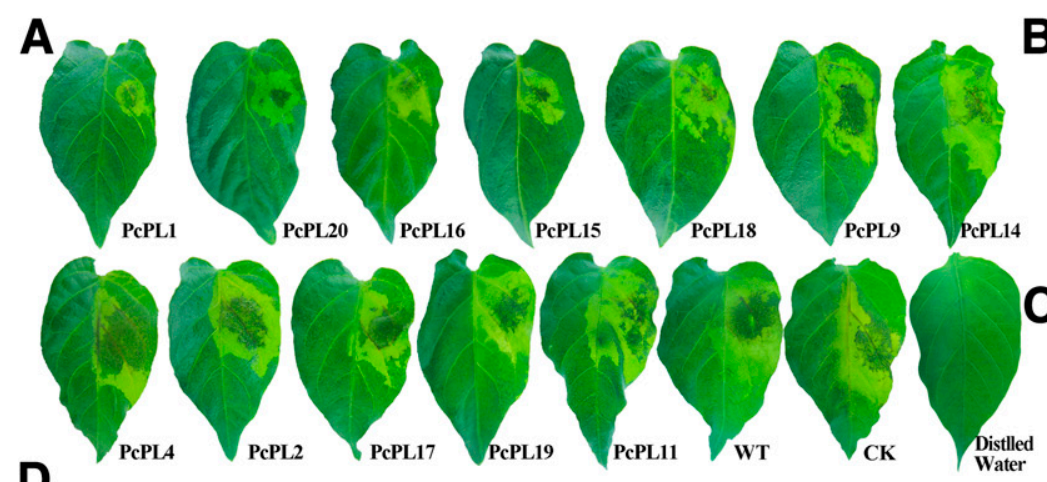

D
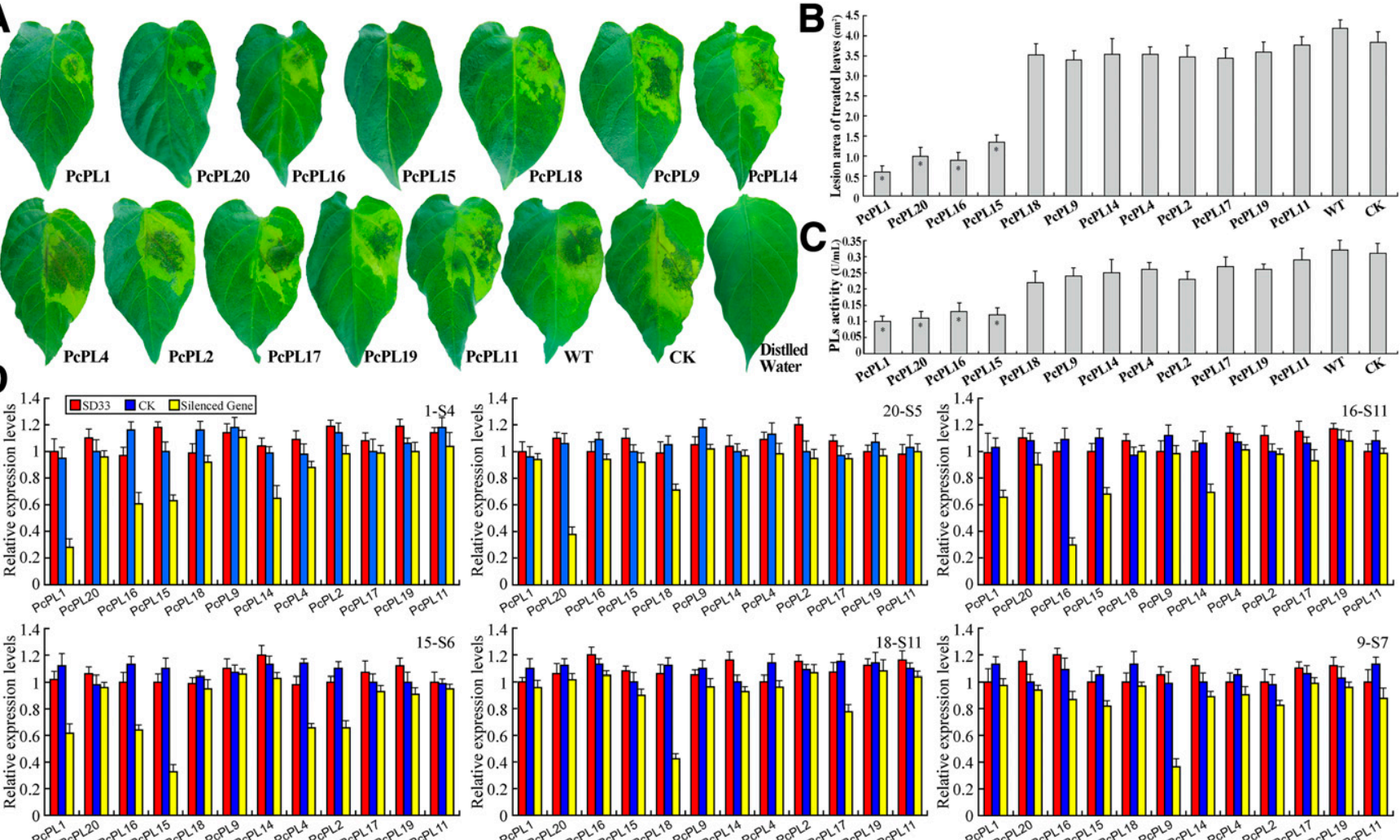

18-S11 ${ }^{1.4}$
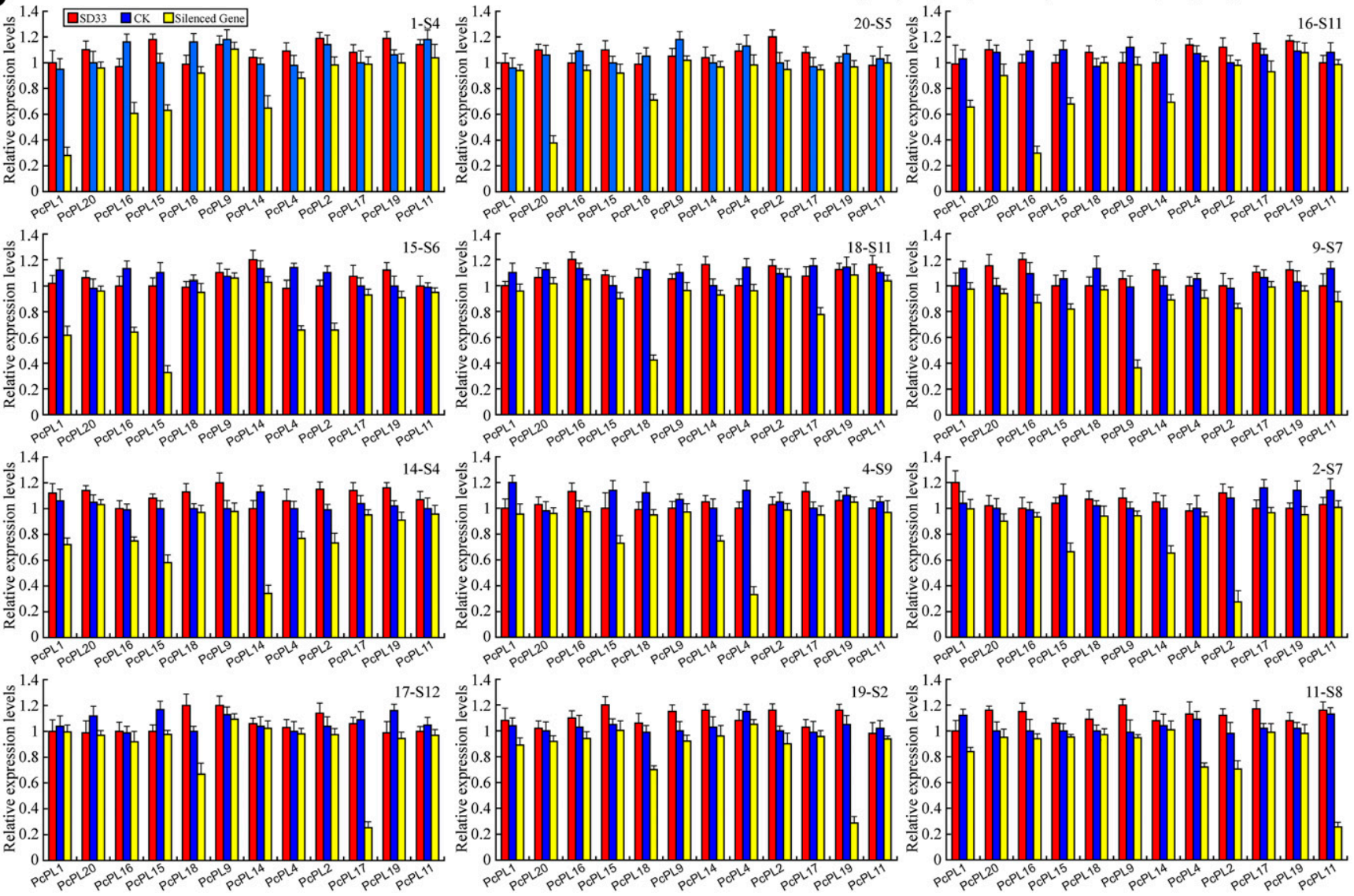

-S2

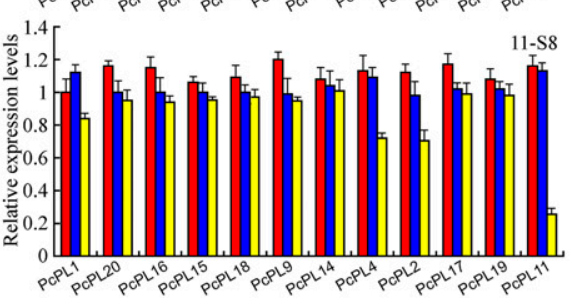

Fig. 5. Cell death response in pepper leaves to inoculation with each silenced Phytophthora capsici line. A, Symptoms appearing on leaves after inoculation with silenced strain containing the following trigger genes: PcPL1 (1-S4), PcPL20 (20-S5), PcPL16 (16-S11), PcPL15 (15-S6), PcPL18 (18-S11), PcPL9 (9S7), PcPL14 (14-S4), PcPL4 (4-S9), PcPL2 (2-S7), PcPL17 (17-S12), PcPL19 (19-S2), PcPL11 (11-S8). A wild type (WT; SD33) and check (CK; SD33 transformed with pHspNpt vector DNA) were used as positive controls. Distilled water was used as a negative control. B, Areas of lesions on pepper leaves were evaluated at 5 days postinoculation (dpi). Bars represent the mean \pm standard error of 14 leaves. C, Activity of pectate lyase (PL) in lesion tissue. In B and $\mathrm{C}$, an asterisk $(*)$ indicates that means are significantly different from WT and CK in a paired $t$ test $(P<0.05)$. D, Transcript levels of 12 targeted genes in each of the silenced lines, measured using quantitative reverse-transcription polymerase chain reaction. Transcript levels in each experiment were normalized to the level of the targeted gene in the SD33 control. Error bars represent confidence intervals calculated using three replicates. 
any one of these three genes could substantially boost virulence; presumably sufficient amounts of the complementary PcPL were expressed in each case to support the increase in virulence. Consistent with its inferred weak contribution to virulence, PcPL15 overexpression most weakly enhanced virulence of SD33 and YN07. Overexpression of PcPLA, which induced weak cell death when expressed in pepper tissue, did not significantly elevate the virulence of SD33 or YN07, further supporting the hypothesis that the ability of the PCPL proteins to trigger cell death is important for their contributions to virulence.

Our current results do not clearly indicate whether the PcPL trigger cell death when expressed at their natural levels during infection, or whether the cell death observed in the agroinfiltration assays is an artifact of overexpression. Thus, it is not yet determined whether the ability to trigger cell death per se is important for virulence, or whether some other activity of the proteins such as pectate degradation is the key contribution. Likewise, our data do not reveal the mechanism of cell death, including whether the PL enzyme activity is required; in future, this could be tested with specific active site mutants. Our results also do not indicate whether the silenced lines are still able to spread biotrophically beyond the regions of tissue collapse.

In $C$. coccodes, deletion of the PL gene CcpelA resulted in a substantial loss of virulence on green tomato fruit (Ben-Daniel et al. 2012). Furthermore, as in our study, in a mildly virulent isolate in which expression of the endogenous CcpelA gene was delayed, overexpression of the CcpelA restored the virulence of transformants to levels comparable with naturally highly virulent isolates (Ben-Daniel et al. 2012). In C. gloeosporoides, delection of the PL gene PelB also reduced virulence on avocado fruit (Yakoby et al. 2001). However, there have been many reports in which deletion of one or more genes encoding PL, pectin lyases, PG, or xylanases have failed to reduce the virulence of plant-pathogenic bacteria or fungi (Yakoby et al. 2001). For example, in D. dadantii (E. chrysathemi), deletion of four PL genes (PelB to -E) had no effect on virulence against pea, and only deletion of PelA substantially reduced virulence (Barras et al. 1994). Interestingly, however, there were hostspecific requirements, because deletion of PelD and PelE did reduce virulence on Saintpaulia (Barras et al. 1994). In our study, only 3 PL genes, out of 22 encoded in the genome, appeared to contribute directly to virulence, underlining the importance of a systematic approach when attempting to unravel the contributions of these large complex protein families to virulence.

It is currently unclear why the $P$. capsici genome contains many PL genes, when only a small number appear to contribute directly to virulence, and some are not transcribed. Several other major oomycete virulence gene families include large numbers of members with overlapping functions as well as many that are silent (Jiang and Tyler 2012; Tyler and Gijzen 2014), including RxLR effectors (Jiang et al. 2008; Wang et al. 2011b), crinkler effectors (Haas et al. 2009; Shen et al. 2013; Stam et al. 2013), and NLP toxin genes (Gijzen and Nürnberger 2006). We speculate that the generation of large virulence gene families through gene duplication and diversification, together with epigenetic remodeling of expression patterns (Qutob et al. 2013), may be a genomic strategy for rapid adaptation by oomycete pathogens (Jiang and Tyler 2012; Tyler and Gijzen 2014).

All of the 12 strongly expressed $P c P L$ genes, including $P C P L 1, P c P L 16$, and PCPL20, showed low expression early in infection, followed by strong induction by 5 and especially 7 days. This observation, together with the correlation between cell-deathinducing activity and virulence, suggests that these genes make their contribution to virulence during the necrotrophic phase, late in infection. However, premature expression of the genes in overexpression transformants did not appear to interfere with virulence but, rather, the virulence was enhanced on both pepper and tobacco.

Our observations indicate that two classes of PL are jointly responsible for virulence on pepper in $P$. capsici; namely, those corresponding to cluster II (PCPL1 and PcPL16) and cluster I (PcPL20) in Supplementary Figure S1. The requirement for both cluster I and cluster II enzymes suggests that the two enzyme families may serve different, complementary functions, in addition to their ability to rapidly trigger cell death. The cluster II enzymes were annotated as belonging to the Pec_Lyase_C family (CDD: 214765; pfam00544; CAZY family PL1) while the cluster I
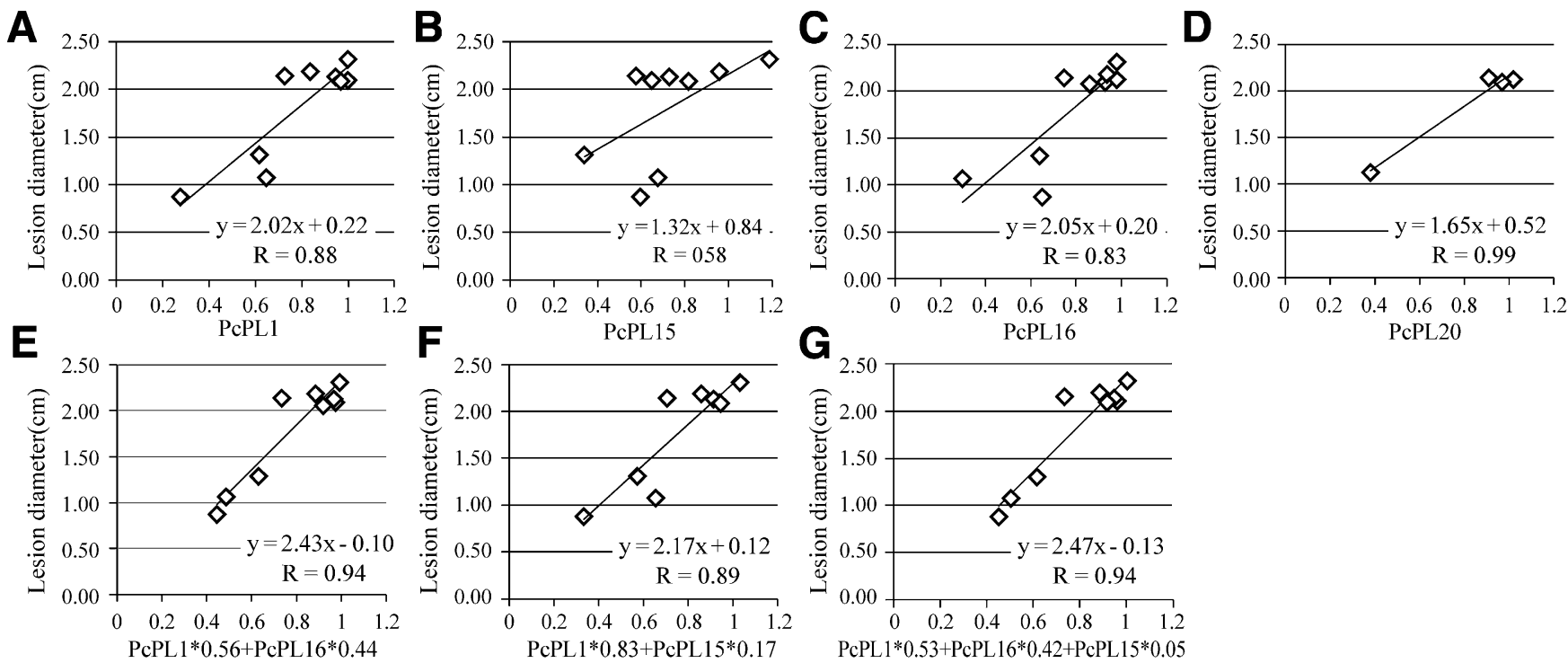

Fig. 6. Correlation and regression analysis of the relationship of transcript levels to lesion sizes. Correlation and regression of lesion diameters (calculated from lesion areas) was carried out with weighted averages of one or more relative transcript levels measured in the silenced lines. A to D, Regression with individual transcript levels. $\mathbf{E}$ to $\mathbf{G}$, Regression with various weighted averages optimized by using stepwise multiple regression. In D, data are from transformants silenced with cluster I PcPL genes (17-S12, 18-S11, 19-S2, and 20-S5). In A to C and E to G, data are from transformants silenced with cluster II PcPL genes (1-S4, 2-S7, 4-S9, 9-S7, 11-S8, 14-S4, 15-S6, and 16-S11). Each graph shows the regression parameters $(\mathrm{y}=$ lesion diameter; $\mathrm{x}=$ transcript average) and the Pearson's correlation coefficient ( $r$. Only PcPL1, PcPL15, PcPL16, and PcPL20 transcript levels showed significant correlations with lesion sizes. 
enzymes were annotated as belonging to the pectate_lyase family (CDD: 251801; pfam03211; CAZY family PL3) of PL. PL from both clusters are abundant in numerous fungal plant pathogens, suggesting that the two functions are also required for fungal pathogenesis. Interestingly, however, Blast searches among other oomycete pathogens revealed that the obligately biotrophic plant pathogens Albugo candida and Plasmopora viticola contain homologs of the cluster I enzymes but not of the cluster II enzymes. In contrast, cluster II homologs but not cluster I homologs could be found in Saprolegnia parasitica and S. diclina; these two aquatic oomycetes are pathogens of fish but also contain genes suggesting that they can also grow as saprophytes on dead plant material (or possibly as epiphytes). This observation hints that perhaps the cluster I enzymes might play a role in suppression of plant immunity (for example, by destroying pectic fragments that act as DAMPs) whereas the role of the cluster II enzymes might be primarily nutritional. Although both cluster I and II enzymes triggered cell death, it is not ruled out that this is an artifact of overexpression. Further work will be required to tease out the exact contributions of each of these enzymes to virulence.

In summary, of the 22 predicted $P c P L$ genes, only 12 showed strong induction during infection and only 4 could trigger strong cell death. Of these four, three appeared responsible for most of the contribution of $P c P L$ genes to virulence. The three genes encompassed two different classes of PL which appeared to make different complementary contributions to virulence.

\section{MATERIALS AND METHODS}

\section{Phytophthora strain cultivation, PL extraction, and activity assay.}

Highly virulent Phytophthora capsici strain SD33 and mildly virulent $P$. capsici strain YN07 were cultured on 10\% V8-juice agar medium at $25^{\circ} \mathrm{C}$. Sporangia and zoospore production were performed as previously described (Erwin and Ribeiro 1996). We manually counted the number of zoospores in $10 \mu \mathrm{l}$ of zoospore suspension. The crude enzymes were extracted from $P$. capsici lesions on pepper leaf, SD33, or YN07, as described by Sella et al. (2004). The PL activity was measured as previously described (Matsumoto et al. 2003).

\section{Isolation of $P c P L$ genes and sequence analysis.}

The $P c P L$ genes were identified in the $P$. capsici genome by searching a six-frame translation for the conserved AxDIKGxxxxVTxS, VxxRxPxxRxGxxHxxxN, and vWiDH motifs and then searching the positive sequences for signal peptides with the tool SignalP4.0. The candidate protein sequences were submitted to the online SMART software to identify conserved functional domains. PL sequences of $P$. sojae (PSPL) and $P$. ramorum $(P r P L)$ were downloaded from the Department of Energy (DOE) Joint Genome Institute (JGI) website. PL sequences of $P$. infestans $(P i P L)$ and $P$. parasitica $(P p P L)$ were downloaded from Broad Institute website. To amplify $P c P L$ genes and $P \operatorname{cinf} 1$ from SD33 and YN07, primers were designed using the Primer Express 3.0 software on PCPL sequences in JGI. Pcinf1 is an elicitin protein (Kamoun et al. 1997a) which was used as a positive control. Genomic DNA of SD33 and YN07 was extracted from mycelia as described by Tyler et al. (1995). The PCR and sequencing were performed as described by Jia et al. (2009). To generate a phylogenetic tree, the 22 PcPL sequences and the additional PL sequences from other Phytophthora spp. were analyzed using Clustal X (2.0) (Thompson et al. 1997).

RNA extraction and SYBR green real-time RT-PCR assay.

To determine the transcript profiles of the PcPL and Pcinf 1 genes during $P$. capsici infection, leaves of pepper line 06221 were inoculated with zoospores from SD33 and YN07 (Sun et al. 2009).
Samples were collected at 1,3,5, and 7 dpi and immediately put into liquid nitrogen. Total RNA extraction and quantification from frozen lesions or filtered mycelium of SD33 and YN07 were performed as previously reported (Feng et al. 2014). Primers (Supplementary Table S4) were designed to anneal specifically to each targeted gene. Three housekeeping genes ( $\beta$-actin, $\beta$-tubulin, and Ubc) of P. capsici (Yan and Liou 2006) were used as constitutively expressed endogenous controls and were used to normalize the expression of the targeted genes. The expression of $P c P L$ genes was determined by qRT-PCR. The PCR and parameters were adjusted slightly from those previously reported (Feng et al. 2014). The values of threshold cycles (CT) were ascertained automatically by the instrument, and the fold changes of individual genes were calculated using the equation $2^{-\Delta \Delta C T}$ according to previous descriptions (Pfaffl 2001). All experiments were carried out in at least three replicates.

\section{Correlation and regression analysis.}

Correlation (Pearson's) and regression (least squares) analysis were carried out using Microsoft Excel. Stepwise multiple regression was carried out by adding transcript levels (e.g., PcPL1, PcPL16, and so on) to a weighted average in order of correlation with lesion sizes, and then finding the weights that optimized correlation of the new weighted average with the LD. Lesion areas were converted to nominal LD by the formula $\mathrm{LD}=2 \sqrt{ }(\mathrm{LA} / \pi)$. Correlation and regression analysis using the lesion areas directly produced similar results to use of LD but the resulting correlations were lower.

\section{Construction of recombinant Agrobacterium tumefaciens binary PVX vectors.}

The $P c P L$ genes that were functionally characterized are listed in Supplementary Table S1. The primers cloning the genes into the PVX vector pGR106 (Supplementary Table S5) were designed to include restriction site overhangs for cloning into the vector pGR106 (Wu et al. 2008). Upstream primers were designed to ensure that the amplified sequences included the native signal peptide for extracellular targeting. The recombinant plasmids were introduced into Agrobacterium tumefaciens GV3101. Individual colonies were toothpick inoculated onto 5-week-old pepper leaves, as described by Feng et al. (2014). Colonies harboring Pcinf 1 , used as a positive control, were inoculated onto the same position on the opposite side (left or right) of the leaf as the $P C P L$ inoculation. The empty vector and distilled water were used as negative controls. Symptom development was monitored visually from 3 to 7 dpi but symptoms were scored and photographed at 3 dpi. All tests were carried out in three replicates.

\section{Protein extraction and Western blots.}

Proteins were extracted from $P$. capsici-infected pepper (line 06221) leaves at $5 \mathrm{dpi}$, following visual recording of the degree of cell death. Proteins were extracted and concentrated from lesion tissues from sets of 14 leaves, as described (Wang et al. 2013), and assayed by the method of Bradford (1976). Lesion tissues expressing Pcinf 1 with a hemagglutinin tag (by agroinfiltration) were used as a positive control. Uninfected pepper leaf proteins were used as negative control. Approximately $50 \mu \mathrm{g}$ of total protein was loaded on each lane of a $12 \%$ sodium dodecyl sulfate polyacrylamide gel electrophoresis gel, using equivalent amounts of protein in each lane. Western blotting was performed as previously described (Wang et al. 2013). Each experiment was repeated at least three times.

\section{Construction of recombinant plasmids} for stable transformations of $\boldsymbol{P}$. capsici.

We used the plasmid vectors pHam34 and pHspNpt to make transformation constructs. Fragments for generating constructs 
were amplified from cDNA, then cloned into pHam34 digested with SmaI. The inserts were verified by DNA sequencing. Primers are listed in Supplementary Table S6. Both sense and antisense plasmids were used for transformations, depending on the objective. A negative (antisense) orientation was used for silencing, while a positive (sense) orientation was used for overexpression (Whisson et al. 2005). The preparation of $P$. capsici protoplasts and the stable transformations were carried out essentially as described by McLeod et al. (2008), with minor adjustments. The transcript levels of the targeted $P c P L$ genes in silenced and overexpressed transformants were determined as described above, with three biological replicates. As an empty vector control (CK) for many experiments, $\mathrm{pHspNpt}$ vector DNA was transformed into the protoplasts of SD33.

\section{Trypan blue staining.}

Upon inoculation of $P$. capsici, leaf discs containing zoospore droplets were excised at $5 \mathrm{dpi}$ and stained with lactophenol-trypan blue solution $(10 \mathrm{ml}$ of lactic acid, $10 \mathrm{ml}$ of glycerol, $9.3 \mathrm{ml}$ of phenol, $10 \mathrm{ml}$ of distilled water, and $20 \mathrm{mg}$ of trypan blue) diluted 1:2 in ethanol, as described (Yeom et al. 2012). The leaf discs were vacuum infiltrated with the staining solution for $5 \mathrm{~min}$, boiled in the solution for $1 \mathrm{~min}$, then incubated overnight in the solution, before being cleared with chloral hydrate $\left(2.5 \mathrm{~g} \mathrm{ml}^{-1}\right)$. The cleared leaf discs were mounted in 50\% glycerol solution and were observed using an OLYMPUS BX-53 microscope.

\section{Analysis of colony growth and sporangial morphology of silenced and overexpressed lines.}

For growth assays, SD33, YN07, and all transformants were subcultured twice on 10\% V8-juice agar medium in the absence of G418. The colony radii of the different strains were measured at $1,3,5$, and 7 dpi. To analyze sporangia production and zoospore release, all test strains were individually cultured and induced under suitable conditions (Jia et al. 2009). The size of sporangia or number of zoospores were determined as described (Masago et al. 1977). Each test was repeated at least three times.

\section{Pepper and tobacco seedling cultivation and leaf inoculation.}

The seedlings of pepper line 06221 and tobacco (N. tabacum L., NC89) were cultivated as previously described (Feng et al. 2014). P. capsici PcPL-silenced lines, overexpression lines, and controls (SD33, YN07, and CK) were induced to produce zoospores, and then each leaflet was spot incubated with $2.0 \mu \mathrm{l}$ of zoospores of the relevant lines $\left(1 \times 10^{5}\right.$ zoospores $\left./ \mathrm{ml}\right)$. Distilled water was used as negative control. The sizes of the lesions were measured and photographed at $3 \mathrm{dpi}$. Tobacco is relatively resistant to infection by P. capsici (Vega-Arreguin et al. 2014) and the control lines produced lesions that were restricted to the site of inoculation. Mean areas of lesions was also calculated at $5 \mathrm{dpi}$. Bars represent the mean \pm standard error of 14 leaves $(P<0.05)$. The tests were repeated three times with at least 14 pepper or tobacco leaves in each experiment.

\section{ACKNOWLEDGMENTS}

We thank K. Lamour for kindly providing the $P$. capsici genome sequence. This work was supported by Special Fund for Agro-scientific Research in the Public Interest of China (201003004).

\section{LITERATURE CITED}

Barras, F., van Gijsegem, F., and Chatterjee, A. K. 1994. Extracellular enzymes and pathogenesis of soft-rot Erwinia. Annu. Rev. Phytopathol. 32:201-234.

Ben-Daniel, B. H., Bar-Zvi, D., and Tsror Lahkim, L. 2012. Pectate lyase affects pathogenicity in natural isolates of Colletotrichum coccodes and in pelA gene-disrupted and gene-overexpressing mutant lines. Mol. Plant Pathol. 13:187-197.

Birch, P. R. J., Boevink, P. C., Gilroy, E. M., Hein, I., Pritchard, L., and Whisson, S. C. 2008. Oomycete RXLR effectors: Delivery, functional redundancy and durable disease resistance. Curr. Opin. Plant Biol. 11: 373-379.

Bradford, M. M. 1976. A rapid and sensitive method for the quantitation of microgram quantities of protein utilizing the principle of protein-dye binding. Anal. Biochem. 72:248-254.

Cantu, D., Vicente, A. R., Labavitch, J. M., Bennett, A. B., and Powell, A. L. 2008. Strangers in the matrix: Plant cell walls and pathogen susceptibility. Trends Plant Sci. 13:610-617.

Charkowski, A. O., Alfano, J. R., Preston, G., Yuan, J., He, S. Y., and Collmer, A. 1998. The Pseudomonas syringae pv. tomato HrpW protein has domains similar to harpins and pectate lyases and can elicit the plant hypersensitive response and bind to pectate. J. Bacteriol. 180:5211-5217.

Collmer, A., and Keen, N. T. 1986. The role of pectic enzyme in plant pathogenesis. Annu. Rev. Phytopathol. 24:383-409.

De Lorenzo, G., Cervone, F., Hahn, M. G., Darvill, A., and Albersheim, P. 1991. Bacterial endopectate lyase: Evidence that plant cell wall $\mathrm{pH}$ prevents tissue maceration and increases the half-life of elicitor-active oligogalacturonides. Physiol. Mol. Plant Pathol. 39:335-344.

Dong, S., Yu, D., Cui, L., Qutob, D., Tedman-Jones, J., Kale, S. D., Tyler, B. M., Wang, Y., and Gijzen, M. 2011. Sequence variants of the Phytophthora sojae RXLR effector Avr3a/5 are differentially recognized by Rps3a and Rps5 in soybean. PLoS One 6:e20172.

Erwin, D. C., and Ribeiro, O. K. 1996. Phytophthora Diseases Worldwide. American Phytopathological Society Press, St. Paul, MN.

Fagard, M., Dellagi, A., Roux, C., Périno, C., Rigault, M., Boucher, V., Shevchik, V. E., and Expert, D. 2007. Arabidopsis thaliana expresses multiple lines of defense to counterattack Erwinia chrysanthemi. Mol. Plant-Microbe Interact. 20:794-805.

Feng, B. Z., Zhu, X. P., Fu, L., Lv, R. F., Storey, D., Tooley, P., and Zhang, X. G. 2014. Characterization of necrosis-inducing NLP proteins in Phytophthora capsici. BMC Plant Biol. 14:126.

Fu, L., Wang, H. Z., Feng, B. Z., and Zhang, X. G. 2013. Cloning, expression, purification and initial analysis of a novel pectate lyase Pcpel1 from Phytophthora capsici. J. Phytopathol. 161:230-238.

Gijzen, M., and Nürnberger, T. 2006. Nep1-like proteins from plant pathogens: Recruitment and diversification of the NPP1 domain across taxa. Phytochemistry 67:1800-1807.

Haas, B. J., Kamoun, S., Zody, M. C., Jiang, R. H., Handsaker, R. E., Cano, L. M., Grabherr, M., Kodira, C. D., Raffaele, S., Torto-Alalibo, T., Bozkurt, T. O., Ah-Fong, A. M., Alvarado, L., Anderson, V. L., Armstrong, M. R., Avrova, A., Baxter, L., Beynon, J., Boevink, P. C., Bollmann, S. R., Bos, J. I., Bulone, V., Cai, G., Cakir, C., Carrington, J. C., Chawner, M., Conti, L., Costanzo, S., Ewan, R., Fahlgren, N., Fischbach, M. A., Fugelstad, J., Gilroy, E. M., Gnerre, S., Green, P. J., Grenville-Briggs, L. J., Griffith, J., Grünwald, N. J., Horn, K., Horner, N. R., Hu, C. H., Huitema, E., Jeong, D. H., Jones, A. M., Jones, J. D., Jones, R. W., Karlsson, E. K., Kunjeti, S. G., Lamour, K., Liu, Z., Ma, L., Maclean, D., Chibucos, M. C., McDonald, H., McWalters, J., Meijer, H. J., Morgan, W., Morris, P. F., Munro, C. A., O’Neill, K., Ospina-Giraldo, M., Pinzón, A., Pritchard, L. Ramsahoye, B., Ren, Q., Restrepo, S., Roy, S., Sadanandom, A., Savidor, A., Schornack, S., Schwartz, D. C., Schumann, U. D., Schwessinger, B., Seyer, L., Sharpe, T., Silvar, C., Song, J., Studholme, D. J., Sykes, S., Thines, M., van de Vondervoort, P. J., Phuntumart, V., Wawra, S., Weide, R., Win, J., Young, C., Zhou, S., Fry, W., Meyers, B. C., van West, P., Ristaino, J., Govers, F., Birch, P. R., Whisson, S. C., Judelson, H. S., and Nusbaum, C. 2009. Genome sequence and analysis of the Irish potato famine pathogen Phytophthora infestans. Nature 461:393-398.

Jia, Y. J., Feng, B. Z., and Zhang, X. G. 2009. Polygalacturonase, Pectate lyase and pectin methylesterase activity in pathogenic strains of Phytophthora capsici incubated under different conditions. J. Phytopathol. 157:585-591.

Jiang, R. H. Y., Tripathy, S., Govers, F., and Tyler, B. M. 2008. RXLR effector reservoir in two Phytophthora species is dominated by a single rapidly evolving superfamily with more than 700 members. Proc. Natl. Acad. Sci. U.S.A. 105:4874-4879.

Jiang, R. H. Y., and Tyler, B. M. 2012. Mechanisms and evolution of virulence in oomycetes. Annu. Rev. Phytopathol. 50:295-318.

Kamoun, S., Lindqvist, H., and Govers, F. 1997a. A novel class of elicitinlike genes from Phytophthora infestans. Mol. Plant-Microbe Interact. 10:1028-1030.

Kotoujansky, A. 1987. Molecular genetics of pathogenesis by soft rot Erwinia. Annu. Rev. Phytopathol. 25:405-430.

Lamour, K. H., Mudge, J., Gobena, D., Hurtado-Gonzales, O. P., Schmutz, J., Kuo, A., Miller, N. A., Rice, B. J., Raffaele, S., Cano, L. M., Bharti, A. K., Donahoo, R. S., Finley, S., Huitema, E., Hulvey, J., Platt, D., 
Salamov, A., Savidor, A., Sharma, R., Stam, R., Storey, D., Thines, M., Win, J., Haas, B. J., Dinwiddie, D. L., Jenkins, J., Knight, J. R., Affourtit, J. P., Han, C. S., Chertkov, O., Lindquist, E. A., Detter, C., Grigoriev, I. V., Kamoun, S., and Kingsmore, S. F. 2012a. Genome sequencing and mapping reveal loss of heterozygosity as a mechanism for rapid adaptation in the vegetable pathogen Phytophthora capsici. Mol. Plant-Microbe Interact. 25:1350-1360.

Lamour, K. H., Stam, R., Jupe, J., and Huitema, E. 2012b. The oomycete broad-host-range pathogen Phytophthora capsici. Mol. Plant Pathol. 13: 329-337.

Masago, H., Yoshikawa, M., Fukada, M., and Nikanishi, N. 1977. Selective inhibition of Pythium sp. on a medium for direct isolation of Phytophthora sp. from soil and plants. Phytopathology 67:425-428.

Matsumoto, H., Jitareerat, P., Baba, Y., and Tsuyumu, S. 2003. Comparative study of regulatory mechanisms for pectinase production by Erwinia carotovora subsp. carotovora and Erwinia chrysanthemi. Mol. PlantMicrobe Interact. 16:226-237.

McLeod, A., Fry, B. A., Zuluaga, A. P., Myers, K. L., and Fry, W. E. 2008. Toward improvements of oomycete transformation protocols. J. Eukaryot. Microbiol. 55:103-109.

Morgan, W., and Kamoun, S. 2007. RXLR effectors of plant pathogenic oomycetes. Curr. Opin. Microbiol. 10:332-338.

Norman-Setterblad, C., Vidal, S., and Palva, E. T. 2000. Interacting signal pathways control defense gene expression in Arabidopsis in response to cell wall-degrading enzymes from Erwinia carotovora. Mol. PlantMicrobe Interact. 13:430-438.

Pfaffl, M. W. 2001. A new mathematical model for relative quantification in real-time RT-PCR. Nucleic Acids Res. 29:e45.

Qutob, D., Chapman, B. P., and Gijzen, M. 2013. Transgenerational gene silencing causes gain of virulence in a plant pathogen. Nat. Commun. 4:1349.

Sella, L., Castiglioni, C., Roberti, S., D’Ovidio, R., and Favaron, F. 2004 An endo-polygalacturonase (PG) of Fusarium moniliforme escaping inhibition by plant polygalacturonase-inhibiting proteins (PGIPs) provides new insights into the PG-PGIP interaction. FEMS Microbiol. Lett. 240:117-124.

Shen, D., Liu, T., Ye, W., Liu, L., Liu, P., Wu, Y., Wang, Y., and Dou, D. 2013. Gene duplication and fragment recombination drive functional diversification of a superfamily of cytoplasmic effectors in Phytophthora sojae. PLoS One 8:e70036.

Song, T., Kale, S. D., Arredondo, F. D., Shen, D., Su, L., Liu, L., Wu, Y., Wang, Y., Dou, D., and Tyler, B. M. 2013. Two RxLR avirulence genes in Phytophthora sojae determine soybean Rps $1 \mathrm{k}$-mediated disease resistance. Mol. Plant-Microbe Interact. 26:711-720.

Stam, R., Jupe, J., Howden, A. J., Morris, J. A., Boevink, P. C., Hedley, P. E., and Huitema, E. 2013. Identification and Characterisation CRN Effectors in Phytophthora capsici Shows Modularity and Functional Diversity. PLoS One 8:e59517.

Sun, W. X., Jia, Y. J., Feng, B. Z., O’Neill, N. R., Zhu, X. P., Xie, B. Y., and Zhang, X. G. 2009. Functional analysis of Pcipg2 from the straminopilous plant pathogen Phytophthora capsici. Genesis 47:535-544.

Thompson, J. D., Gibson, T. J., Plewniak, F., Jeanmougin, F., and Higgins, D. G. 1997. The CLUSTAL_X windows interface: Flexible strategies for multiple sequence alignment aided by quality analysis tools. Nucleic Acids Res. 25:4876-4882.

Tyler, B. M., Forster, H., and Coffey, M. D. 1995. Inheritance of avirulence factors and restriction fragment length polymorphism markers in outcrosses of the oomycete Phytophthora sojae. Mol. Plant-Microbe Interact. 8:515-523.

Tyler, B. M., and Gijzen, M. J. 2014. The Phytophthora sojae genome sequence: Foundation for a revolution. Pages 133-157 in: Genomics of Plant-Associated Fungi and Oomycetes: Dicot Pathogens. R. A. Dean, A. Lichens-Park, and C. Kole, eds. Springer, Heidelberg, Germany.
Tyler, B. M., Tripathy, S., Zhang, X., Dehal, P., Jiang, R. H., Aerts, A., Arredondo, F. D., Baxter, L., Bensasson, D., Beynon, J. L., Chapman, J., Damasceno, C. M., Dorrance, A. E., Dou, D., Dickerman, A. W., Dubchak, I. L., Garbelotto, M., Gijzen, M., Gordon, S. G., Govers, F., Grunwald, N. J., Huang, W., Ivors, K. L., Jones, R. W., Kamoun, S., Krampis, K., Lamour, K. H., Lee, M. K., McDonald, W. H., Medina, M., Meijer, H. J., Nordberg, E. K., Maclean, D. J., Ospina-Giraldo, M. D., Morris, P. F., Phuntumart, V., Putnam, N. H., Rash, S., Rose, J. K., Sakihama, Y., Salamov, A. A., Savidor, A., Scheuring, C. F., Smith, B. M., Sobral, B. W., Terry, A., Torto-Alalibo, T. A., Win, J., Xu, Z., Zhang, H., Grigoriev, I. V., Rokhsar, D. S., and Boore, J. L. 2006. Phytophthora genome sequences uncover evolutionary origins and mechanisms of pathogenesis. Science 313:1261-1266.

Vega-Arreguin, J. C., Jalloh, A., Bos, J. I., and Moffett, P. 2014. Recognition of an Avr3a homologue plays a major role in mediating non-host resistance to Phytophthora capsici in Nicotiana species. Mol. Plant-Microbe Interact. 27:770-780.

Wang, H., Fu, L., and Zhang, X. 2011a. Comparison of expression, purification and characterization of a new pectate lyase from Phytophthora capsici using two different methods. BMC Biotechnol. 11:32.

Wang, Q., Han, C., Ferreira, A. O., Yu, X., Ye, W., Tripathy, S., Kale, S. D., Gu, B., Sheng, Y., Sui, Y., Wang, X., Zhang, Z., Cheng, B., Dong, S., Shan, W., Zheng, X., Dou, D., Tyler, B. M., and Wang, Y. 2011b. Transcriptional programming and functional interactions within the Phytophthora sojae RXLR effector repertoire. Plant Cell 23:2064-2086.

Wang, X., Zhu, X., Tooley, P., and Zhang, X. 2013. Cloning and functional analysis of three genes encoding polygalacturonase-inhibiting proteins from Capsicum annuum and transgenic CaPGIP1 in tobacco in relation to increased resistance to two fungal pathogens. Plant Mol. Biol. 81: 379-400.

Wattad, C., Kobiler, D., Dinoor, A., and Prusky, D. 1997. Pectate lyase of Colletotrichum gloeosporioides attacking avocado fruits: cDNA cloning and involvement in pathogenicity. Physiol. Mol. Pathol. 50:197-212.

Whisson, S. C., Avrova, A. O., VAN West, P., and Jones, J. T. 2005. A method for double-stranded RNA-mediated transient gene silencing in Phytophthora infestans. Mol. Plant Pathol. 6:153-163.

Win, J., Morgan, W., Bos, J., Krasileva, K. V., Cano, L. M., Chaparro-Garcia, A., Ammar, R., Staskawicz, B. J., and Kamoun, S. 2007. Adaptive evolution has targeted the C-terminal domain of the RXLR effectors of plant pathogenic oomycetes. Plant Cell 19:2349-2369.

Wu, C. H., Yan, H. Z., Liu, L. F., and Liou, R. F. 2008. Functional characterization of a gene family encoding Polygalacturonases in Phytophthora parasitica. Mol. Plant-Microbe Interact. 21:480-489.

Yakoby, N., Beno-Moualem, D., Keen, N. T., Dinoor, A., Pines, O., and Prusky, D. 2001. Colletotrichum gloeosporioides pelB is an important virulence factor in avocado fruit-fungus interaction. Mol. Plant-Microbe Interact. 14:988-995.

Yan, H. Z., and Liou, R. F. 2006. Selection of internal control genes for real-time quantitative RT-PCR assays in the oomycete plant pathogen Phytophthora parasitica. Fungal Genet. Biol. 43:430-438.

Yeom, S. I., Seo, E., Oh, S. K., Kim, K. W., and Choi, D. 2012. A common plant cell-wall protein HyPRP1 has dual roles as a positive regulator of cell death and a negative regulator of basal defense against pathogens. Plant J. 69:755-768.

Yoder, M. D., Keen, N. T., and Jurnak, F. 1993. New domain motif: The structure of pectate lyase C, a secreted plant virulence factor. Science 260:1503-1507.

\section{AUTHOR-RECOMMENDED INTERNET RESOURCES}

Broad Institute: http://www.broadinstitute.org

CAZy database: www.cazy.org

DOE JGI website: www.jgi.doe.gov 